\title{
Value of surface counting in predicting response to splenectomy in haemolytic anaemia
}

\author{
S. AHUJA, S. M. LEWIS, AND L. SZUR
}

From the Departments of Haematology and Radiotherapy, Royal Postgraduate Medical School, London

SYNOPSIS The value of surface counting with ${ }^{51} \mathrm{Cr}$-labelled red cells in predicting response to splenectomy in haemolytic anaemia has been analysed in 18 cases. The cases included six patients with congenital haemolytic anaemias, four with primary autoimmune haemolytic anaemias, and eight patients with secondary haemolytic anaemias (four with a positive antiglobulin test). All patients showed evidence of splenic accumulation of labelled cells and in 16 of the cases this was confined to the spleen. Improvement followed splenectomy in 17 of the cases although there was no close correlation between the magnitude of accumulation of radioactivity as measured by excess counts and the degree of response. The reasons for these discrepancies are discussed, The only patient who completely failed to respond to splenectomy had a sideroblastic element to the anaemia. It has been concluded that surface counting is of value in selecting patients for splenectomy but should not be depended upon without reference to other clinical and haematological factors, which are likely to influence the prognosis.

The method of surface counting after injection of red cells labelled with radioactive chromium $\left({ }^{51} \mathrm{Cr}\right)$ has been widely used in recent years to determine the site of red cell destruction (Jandl, Greenberg, Yonemoto, and Castle, 1956; Schloesser, Korst, Clatanoff, and Schilling, 1957; Jones and Szur, 1957).

The principle of the method is based on the observation that destruction of red cells in an organ is manifested by progressive increase in radioactive counts over that organ relative to the count rate over other organs and over the heart, reflecting the radioactivity in the blood; thus assessment can be made of the role of the spleen relative to the liver in the destruction of erythrocytes. An accumulation of activity in the spleen suggests that splenectomy might be beneficial and the method has been considered to be a valuable aid in predicting response to splenectomy in the majority of patients with haemolytic anaemia. However, a number of false predictions have been reported by some authors (Schloesser $e t$ al, 1957; McCurdy and Rath, 1958; Veeger, Woldring, Van Rood, Eernisse, Leeksma, Verloop, and Nieweg, 1962; Ben-Bassat, Seligsohn, Leiba, Leef, Chaitchik, and Ramot, 1967; Allgood and Chaplin, 1967). These reports indicate the need for a clear understanding of the method before it is used in making a decision for or against splenectomy.

Received for publication 14 February 1972.
In the present study we have analysed the results of surface counting and their correlation with the response to splenectomy in patients with haemolytic anaemia due to various causes.

\section{Material and Methods}

\section{SUBJECTS}

Eighteen patients with various haemolytic anaemias who underwent splenectomy were studied (Table I). They were broadly classified into (a) congenital haemolytic anaemia, six cases; (b) primary autoimmune haemolytic anaemia, four cases; and (c) secondary haemolytic anaemia, eight cases. In four cases of the last group an autoimmune process was demonstrated by a positive direct antiglobulin test. The effect of splenectomy on the anaemia has been correlated with the results of surface counting.

RED CELL SURVIVAL AND SURFACE COUNTING An aliquot of the patient's red cells was labelled with $100 \mu \mathrm{Ci}$ of ${ }^{51} \mathrm{Cr}$ (as sodium chromate) by a standard method (Dacie and Lewis, 1968). From the rate of elimination of labelled cells from the circulation the half disappearance time $\left({ }^{51} \mathrm{Cr} \mathbf{T}_{50}\right)$ was calculated and the mean cell life (MCL) obtained by plotting the data on graph paper after correcting for elution of ${ }^{51} \mathrm{Cr}$ from the red cells. 


\begin{tabular}{|c|c|c|c|c|c|c|c|c|c|c|c|c|c|}
\hline \multirow{2}{*}{$\begin{array}{l}\text { Case } \\
\text { No. }\end{array}$} & \multirow{2}{*}{ Diagnosis } & \multirow{2}{*}{\multicolumn{2}{|c|}{ Age Sex }} & \multicolumn{5}{|c|}{ Before Splenectomy } & \multicolumn{5}{|c|}{ Afier Splenectomy } \\
\hline & & & & $\begin{array}{l}\mathrm{Hb}(\mathrm{g} / \\
100 \mathrm{ml})\end{array}$ & $\begin{array}{l}P C V \\
(\%)\end{array}$ & $\begin{array}{l}\text { Reticulocytes } \\
(\%)\end{array}$ & $\begin{array}{l}W B C \\
(\operatorname{per} \mu l)\end{array}$ & $\begin{array}{l}\text { Platelets } \\
\times 10^{3} \\
(\text { per } \mu l)\end{array}$ & $\begin{array}{l}H b(\mathrm{gl} \\
100 \mathrm{ml})\end{array}$ & $\begin{array}{l}P C V \\
(\%)\end{array}$ & $\begin{array}{l}\text { Reticulocytes } \\
(\%)\end{array}$ & $\begin{array}{l}W B C \\
(p e r \mu l)\end{array}$ & $\begin{array}{l}\text { Platelets } \\
\times 10^{8} \\
(\text { per } \mu l)\end{array}$ \\
\hline \multirow{5}{*}{$\begin{array}{l}1 \\
2 \\
3 \\
4 \\
5\end{array}$} & Hereditary spherocytosis & 34 & $\mathbf{F}$ & $11 \cdot 4$ & 31 & 20 & 6000 & 770 & $16 \cdot 8$ & 46 & - & 11000 & - \\
\hline & Hereditary spherocytosis & 20 & $\mathbf{M}$ & $10 \cdot 0$ & 29 & 15 & 5000 & 500 & $12 \cdot 0$ & 34 & 6 & 5000 & 322 \\
\hline & Hereditary spherocytosis & 21 & $\mathbf{F}$ & $12 \cdot 2$ & 33 & 9 & 6000 & - & $14 \cdot 3$ & 41 & 4 & 5000 & - \\
\hline & Sickle cell anaemia & 27 & $\mathbf{F}$ & $6 \cdot \overline{5}$ & 21 & 3 & 9000 & 700 & $9 \cdot 5$ & 29 & 12 & 9500 & 700 \\
\hline & $\begin{array}{l}\text { Hereditary elliptocytosis } \\
\text { + dyserythropoietic }\end{array}$ & & & & & & & & & & & & \\
\hline \multirow[t]{2}{*}{6} & $\begin{array}{l}\text { anaemia } \\
\text { Hereditary elliptocytosis }\end{array}$ & 60 & $\mathbf{F}$ & 6.9 & 22 & 4 & 7000 & 570 & $8 \cdot 0$ & 26 & $0 \cdot 2$ & 1300 & 一 \\
\hline & + sideroblastic anaemia & 41 & $\mathbf{M}$ & $5 \cdot 2$ & 16 & 5 & 5000 & 270 & $6 \cdot 5$ & 23 & 5 & 13000 & 800 \\
\hline 7 & AIHA (warm antibody) & 14 & $\mathbf{F}$ & $9 \cdot 0$ & 28 & 12 & 9000 & 245 & $12 \cdot 0$ & 40 & 2 & 8400 & 466 \\
\hline 8 & AIHA (warm antibody) & 50 & $\mathbf{M}$ & $7 \cdot 2$ & 23 & 34 & 10000 & 263 & $13 \cdot 0$ & 36 & 12 & - & - \\
\hline 9 & AIHA (warm antibody) & 72 & $\mathbf{M}$ & $6 \cdot 0$ & 22 & 3 & 10000 & 285 & $14 \cdot 6$ & 44 & 3 & 8200 & 350 \\
\hline 10 & AIHA (warm antibody) & 58 & $\mathbf{F}$ & $5 \cdot 0$ & 18 & 80 & 18000 & 260 & $10 \cdot 0$ & 34 & 8 & 5000 & 322 \\
\hline 11 & Myelofibrosis & 13 & $\mathbf{F}$ & $7 \cdot 0$ & 22 & 10 & 13000 & 51 & $16 \cdot 0$ & 46 & 2 & 17000 & 109 \\
\hline \multirow[t]{2}{*}{$\begin{array}{l}12 \\
13\end{array}$} & $\begin{array}{l}\text { Lymphosarcoma } \\
\text { Hodgkin's disease }\end{array}$ & 50 & $\mathbf{F}$ & $8 \cdot 0$ & 25 & 50 & 5000 & 144 & $16 \cdot 6$ & 48 & 二 & 8700 & 161 \\
\hline & (+ AIHA-warm antibody) & 22 & $\mathbf{M}$ & $6 \cdot 6$ & 20 & 6 & 80000 & 153 & $12 \cdot 9$ & 38 & 0.6 & 3300 & 276 \\
\hline 14 & $\begin{array}{l}\text { Hodgkin's disease } \\
\text { (+ AIHA-warm antibody) }\end{array}$ & 26 & $\mathbf{F}$ & $8 \cdot 5$ & 30 & 15 & 5000 & 271 & $12 \cdot 3$ & 39 & 0.8 & 5000 & 308 \\
\hline \multirow[t]{2}{*}{15} & Chronic lymphocytic & 59 & $\mathbf{M}$ & $9 \cdot 0$ & 28 & 12 & 25000 & 154 & $15 \cdot 0$ & 44 & $1 \cdot 5$ & 19000 & 322 \\
\hline & $\begin{array}{l}\text { leukaemia (AIHA- } \\
\text { warm antibody) }\end{array}$ & 59 & $\mathbf{M}$ & $9 \cdot 0$ & 28 & 12 & 25000 & 154 & $15 \cdot 0$ & 44 & $1 \cdot 5$ & 19000 & 322 \\
\hline \multirow{4}{*}{$\begin{array}{l}16 \\
17\end{array}$} & Hodgkin's disease & 60 & $\mathbf{F}$ & $9 \cdot 0$ & 29 & 12 & 2000 & 148 & $11 \cdot 7$ & 30 & $1 \cdot 4$ & 8000 & 48 \\
\hline & Hodgkins disease & & & & & & & & & & & & \\
\hline & $\begin{array}{l}\text { (+AIHA-cold antibody) } \\
\text { Chronic granulocytic }\end{array}$ & 66 & $\mathbf{M}$ & $7 \cdot 0$ & 21 & 11 & 8000 & 468 & $7 \cdot 0$ & 28 & $3 \cdot 0$ & 16500 & 498 \\
\hline & leukaemia & 18 & $\mathbf{M}$ & $5 \cdot 0$ & 17 & 0.2 & 20000 & 55 & $9 \cdot 0$ & 28 & 1.8 & 8000 & 48 \\
\hline
\end{tabular}

Table I Clinical and haematological data

Surface counting was carried out over the heart, liver, and spleen using a collimated directional scintillation counter incorporating a NaI crystal 3.4 × 2.5 $\mathrm{cm}$ in size. An index of relative accumulation of ${ }^{51} \mathrm{Cr}$ in the spleen and liver was calculated by the excess counts method (Jones and Szur, 1957; Lewis, Szur, and Dacie, 1960). The initial splcen/ liver ratio was taken as 1.0 and all subsequent spleen/liver ratios were adjusted in proportion to this unit. Increased red cell destruction in an organ was indicated by a greater number of excess counts in that organ than is found in normal subjects.

\section{RESPONSE TO SPLENECTOMY}

The response to splenectomy was judged on the basis of repeated haemoglobin estimation after operation, and the frequency of blood transfusion required. Only in six of the patients was it possible to repeat the red cell survival a few months after the operation, as the remaining patients had been referred from hospitals outside London.

The responses were classified as follows:

Grade I Haemoglobin normal; no blood transfusion required

Grade II Haemoglobin improved to subnormal level but maintained adequately; no blood transfusion required

Grade III Haemoglobin falling but at a slower rate than before; transfusion requirement reduced
Grade IV No significant response, ie, haemoglobin falling at approximately the same rate as before $\frac{\mathcal{Q}}{\mathbb{Q}}$ operation; transfusion requirement unchanged.

\section{Results}

Sixteen of the 18 patients showed evidence of increased red cell destruction confined to the spleen (Table II). Fifteen of them benefited from splenectomy and one patient who did not appear to benefit 3 . (case 6) was a case of hereditary elliptocytosis who also had sideroblastic anaemia. The remaining two patients showed evidence of red cell destruction in 0 both spleen and liver. Both these patients responded favourably to splenectomy. It will be noted, however, that in general the magnitude of the excess counts obtained over the spleen did not show a close corre- $O$ lation with the grade of response to splenectomy $N$ (Table III).

\section{Illustrative Case Reports}

A short summary of the case reports in two of the patients is given here as they are considered to be of particular interest and will be referred to specifically in the discussion.

CASE 5

A married woman, aged 52 years, was referred with 


\begin{tabular}{|c|c|c|c|c|c|c|c|}
\hline \multirow[t]{2}{*}{ Anaemia } & \multirow[t]{2}{*}{ Case No. } & \multirow[t]{2}{*}{${ }^{31} \mathrm{Cr} T_{50}($ days $)$} & \multirow[t]{2}{*}{$M C L$ (days) } & \multicolumn{2}{|c|}{ Excess Counts at ${ }^{51} \mathrm{Cr} T_{\mathrm{b0}}$} & \multirow[t]{2}{*}{ Initial S/L Ratio } & \multirow{2}{*}{$\begin{array}{l}\text { Adjusted } S / L \\
\text { Ratio }\end{array}$} \\
\hline & & & & Spleen & Liver & & \\
\hline $\begin{array}{l}\text { Congenital } \\
\text { haemolytic }\end{array}$ & $\begin{array}{l}1 \\
2 \\
3 \\
4 \\
5 \\
6\end{array}$ & $\begin{array}{r}10 \\
9 \\
11 \\
3 \\
15 \\
13\end{array}$ & $\begin{array}{r}25 \\
18 \\
22 \\
5 \\
33 \\
27\end{array}$ & $\begin{array}{r}1000 \\
800 \\
700 \\
1300 \\
1100 \\
450\end{array}$ & $\begin{array}{l}<200 \\
<200 \\
<200 \\
<200 \\
<200 \\
<200\end{array}$ & $\begin{array}{l}1.4 \\
2.5 \\
1.5 \\
1.6 \\
2.6 \\
1.5\end{array}$ & $\begin{array}{l}1 \cdot 5 \\
1 \cdot 5 \\
1 \cdot 3 \\
2 \cdot 2 \\
1 \cdot 3 \\
1 \cdot 3\end{array}$ \\
\hline $\begin{array}{l}\text { Primary } \\
\text { autoimmune } \\
\text { haemolytic }\end{array}$ & $\begin{array}{r}7 \\
8 \\
9 \\
10\end{array}$ & $\begin{array}{r}5 \\
5 \\
12 \\
2\end{array}$ & $\begin{array}{r}9 \\
10 \\
25 \\
4\end{array}$ & $\begin{array}{r}700 \\
500 \\
1400 \\
500\end{array}$ & $\begin{array}{r}400 \\
300 \\
<200 \\
<200\end{array}$ & $\begin{array}{l}3.9 \\
1 \cdot 2 \\
3 \cdot 0 \\
1.8\end{array}$ & $\begin{array}{l}0 \cdot 8 \\
1.4 \\
1 \cdot 8 \\
1 \cdot 3\end{array}$ \\
\hline $\begin{array}{l}\text { Secondary } \\
\text { haemolytic }\end{array}$ & $\begin{array}{l}11 \\
12 \\
13 \\
14 \\
15 \\
16 \\
17 \\
18\end{array}$ & $\begin{array}{r}12 \\
16 \\
6 \\
11 \\
8 \\
17 \\
15 \\
13\end{array}$ & $\begin{array}{l}26 \\
37 \\
12 \\
18 \\
16 \\
30 \\
32 \\
28\end{array}$ & $\begin{array}{r}400 \\
400 \\
1350 \\
500 \\
1000 \\
500 \\
350 \\
750\end{array}$ & $\begin{array}{l}<200 \\
<200 \\
<200 \\
<200 \\
<200 \\
<200 \\
<200 \\
<200\end{array}$ & $\begin{array}{l}1 \cdot 5 \\
1 \cdot 2 \\
2 \cdot 0 \\
3 \cdot 0 \\
2 \cdot 0 \\
2 \cdot 0 \\
3 \cdot 7 \\
2 \cdot 1\end{array}$ & $\begin{array}{l}1.4 \\
1.5 \\
1.9 \\
1.2 \\
2.5 \\
1.3 \\
0.9 \\
1 \cdot 1\end{array}$ \\
\hline
\end{tabular}

Table II Data on preoperative ${ }^{51} \mathrm{Cr}$ survival studies

\begin{tabular}{|c|c|c|c|c|c|c|}
\hline Anaemia & Case No. & $\begin{array}{l}\text { Weight of Spleen } \\
(g)\end{array}$ & $\begin{array}{l}\text { Postoperative } \mathrm{Hb} \\
(\mathrm{g} / 100 \mathrm{ml})\end{array}$ & $\begin{array}{l}\text { Postoperative } \\
\text { Transfusion } \\
\text { Requirement }\end{array}$ & $\begin{array}{l}\text { Postoperative } \\
{ }^{1} \mathrm{Cr} T_{\mathrm{b0}}\end{array}$ & Grade of Response \\
\hline $\begin{array}{l}\text { Congenital } \\
\text { haemolytic }\end{array}$ & $\begin{array}{l}1 \\
2 \\
3 \\
4 \\
5 \\
6\end{array}$ & $\begin{array}{l}225 \\
744 \\
225 \\
612 \\
150 \\
150\end{array}$ & \begin{tabular}{r|}
$16 \cdot 8$ \\
$12 \cdot 0$ \\
$14 \cdot 3$ \\
$9 \cdot 5$ \\
$8 \cdot 0$ \\
$8 \cdot 0$
\end{tabular} & $\begin{array}{l}\text { Nil } \\
\text { Nil } \\
\text { Nil } \\
\text { Nil } \\
\text { Reduced } \\
\text { No change }\end{array}$ & $\begin{array}{l}\overline{-} \\
\overline{-} \\
25 \text { days (3 months) }\end{array}$ & $\begin{array}{l}\text { I } \\
\text { I } \\
\text { I } \\
\text { II } \\
\text { III } \\
\text { IV }\end{array}$ \\
\hline $\begin{array}{l}\text { Primary } \\
\text { autoimmune } \\
\text { haemolytic }\end{array}$ & $\begin{array}{r}7 \\
8 \\
9 \\
10\end{array}$ & $\begin{array}{l}320 \\
368 \\
220 \\
175\end{array}$ & $\begin{array}{l}16 \cdot 0 \\
13 \cdot 0 \\
14 \cdot 6 \\
16 \cdot 8\end{array}$ & $\begin{array}{l}\text { Nil } \\
\text { Nil } \\
\text { Nil } \\
\text { Nil }\end{array}$ & $\begin{array}{l}26 \text { days ( } 5 \text { months })^{1} \\
-\overrightarrow{27} \text { days }(6 \text { months })^{1} \\
10 \text { days ( } 3 \text { months) }\end{array}$ & $\begin{array}{l}\text { I (?II) } \\
\text { I } \\
\text { I } \\
\text { II }\end{array}$ \\
\hline $\begin{array}{l}\text { Secondary } \\
\text { haemolytic }\end{array}$ & $\begin{array}{l}11 \\
12 \\
13 \\
14 \\
15 \\
16 \\
17 \\
18\end{array}$ & $\begin{array}{r}750 \\
760 \\
845 \\
294 \\
980 \\
410 \\
1730 \\
390\end{array}$ & $\begin{array}{r}16 \cdot 8 \\
16 \cdot 6 \\
12.9 \\
12 \cdot 3 \\
15 \cdot 0 \\
11 \cdot 7 \\
7 \cdot 0 \\
9.0\end{array}$ & $\begin{array}{l}\text { Nil } \\
\text { Nil } \\
\text { Nil } \\
\text { Nil } \\
\text { Nil } \\
\text { Nil } \\
\text { Nil } \\
\text { Reduced }\end{array}$ & $\begin{array}{l}\overline{28} \text { days (6 months) } \\
\overline{-} \\
\overline{25} \text { days (6 months) } \\
= \\
=\end{array}$ & $\begin{array}{l}\text { I } \\
\text { I } \\
\text { I } \\
\text { I } \\
\text { I } \\
\text { II } \\
\text { II } \\
\text { III }\end{array}$ \\
\hline
\end{tabular}

Table III Response to splenectomy

${ }^{1}$ Time after operation when cell survival study was performed

a history of several transient attacks of epigastric pain, one of which was followed by jaundice which lasted for a few days. Gallstones and a dilated common bile duct were demonstrated by cholecystogram. She was found to be anaemic with a haemoglobin of $8 \mathrm{~g}$ per $100 \mathrm{ml}$. On examinations she was pale and was not jaundiced. The liver was not felt and the splenic tip was just palpable. A blood film showed moderate anisocytosis, macrocytosis, marked poikilocytosis, and many oval cells. Marrow showed normoblastic hyperplasia with an increased cellularity and abundant iron stores. In the urine there were no bile pigments or urobilinogen. A direct antiglobulin test was negative. Serum iron was 152 $\mu \mathrm{g} / 100 \mathrm{ml}$ and total iron-binding capacity $262 \mu \mathrm{g} / 100$ ml. In a cell survival study ${ }^{51} \mathrm{Cr} \mathbf{T}_{50}$ was 15 days and the mean cell life was 33 days. Surface counting showed evidence of red cell destruction in the spleen with an excess count of 1100 on day 15 (Fig. 1). Radioactive iron studies showed increased iron turnover with poor incorporation into red cells, and in conjunction with the surface counting, the pattern was suggestive of ineffective erythropoiesis.

Cholecystectomy was carried out. Histological examination confirmed cholelithiasis and cholecystitis. The spleen was removed at the same time. A ${ }^{51} \mathrm{Cr}$ study repeated after three months now showed a normal survival of red cells (Fig. 1), although 

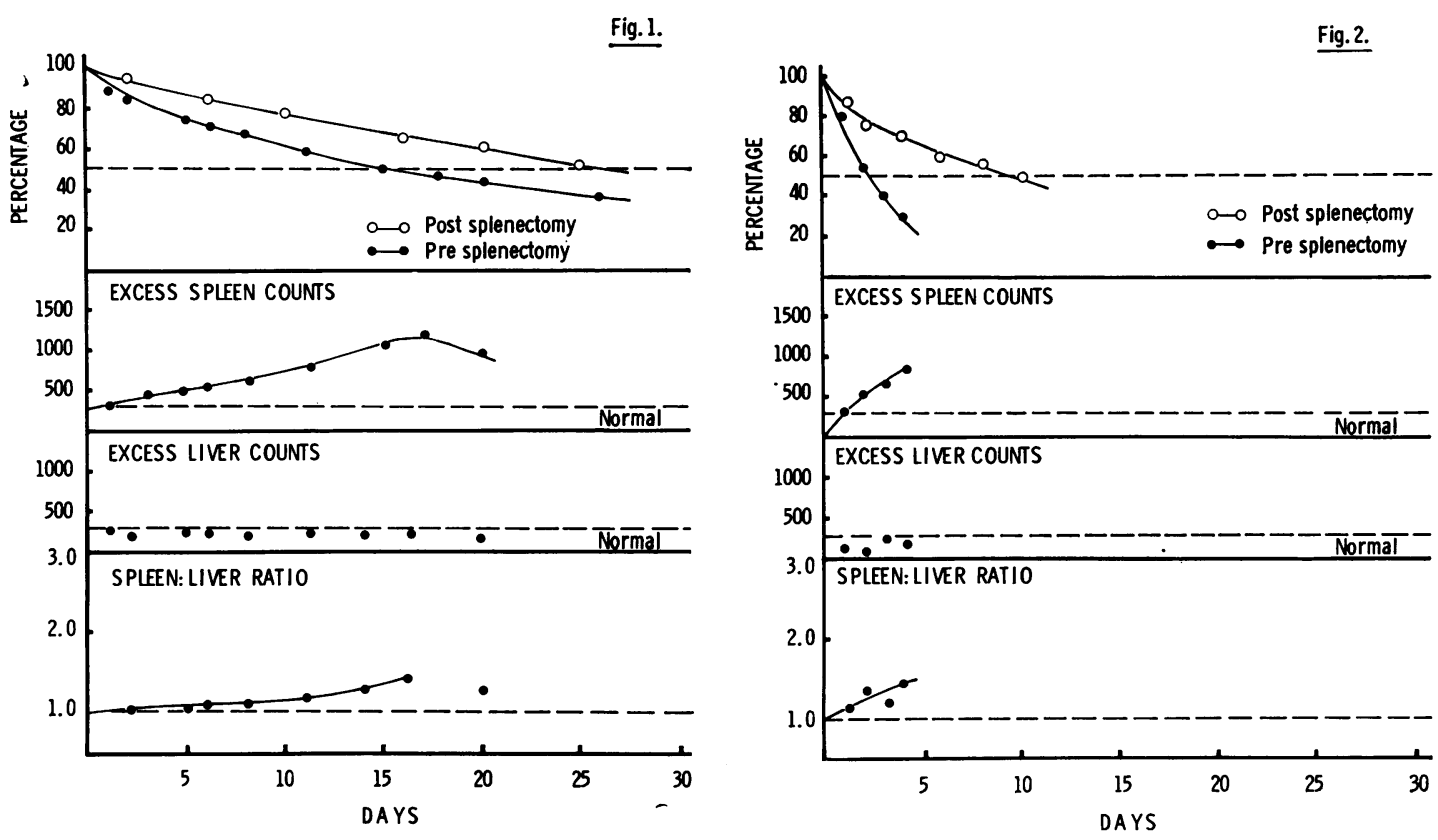

Fig. $1{ }^{51}$ Cr cell survival and surface counting pattern in case 5.

Fig. $2{ }^{51} \mathrm{Cr}$ cell survival and surface counting pattern in case 10.

- Before splenectomy, $\bigcirc$ After splenectomy The cell survival data have not been converted for elution of $C r$ in this graph.

anaemia persisted. This was further investigated: repeat bone marrow clearly showed that the patient had a sideroblastic anaemia.

\section{CASE 10}

A married woman, aged 58 years, was referred with a short history of tiredness and lassitude. Haemoglobin was $5.4 \mathrm{~g} / 100 \mathrm{ml}$ and she had a reticulocyte count of $80 \%$. She had been treated for some weeks at another hospital with Prednisone in doses of up to $300 \mathrm{mg}$ daily without response. She had a moderately strongly positive direct antiglobulin test which was entirely due to IgG antibodies. The marrow showed erythroid hyperplasia with normal erythropoiesis. Serum bilirubin was $3.2 \mathrm{mg} / 100 \mathrm{ml}$ and urine showed the presence of marked amount of haemosiderin.

Radioactive chromium studies showed a markedly reduced red cell survival $\left({ }^{51} \mathrm{Cr} \mathrm{T}_{50}\right.$ of two days, $\mathrm{MCL}$ four days) and evidence of destruction in the spleen (500 excess counts on day 2) (Fig. 2). It was thought that she had both intravascular haemolysis and extravascular red cell destruction predominantly in the spleen. Splenectomy was performed. The histology of the spleen showed only congestion with no specific diagnostic features. Three months after splenectomy the patient's haemoglobin had risen to around $10 \mathrm{~g} / 100 \mathrm{ml}$ and the reticulocyte count had $\overrightarrow{\vec{O}}$ fallen to $8-9 \%$. Red cell survival study was repeated: 3 this showed improvement with a ${ }^{51} \mathrm{Cr} \mathrm{T}_{50}$ of 10 days and a MCL of 24 days (Fig. 2). Two years after splenectomy the haemoglobin was $11.5 \mathrm{~g} / 100 \mathrm{ml}$. The direct antiglobulin test has remained strongly positive.

\section{Discussion}

Four patterns of surface counting has been defined $\stackrel{ }{ }$ (Lewis et al, 1960): (1) excess accumulation in spleen $\frac{D}{O}$ only; (2) excess accumulation in liver only; (3) excess accumulation in both spleen and liver; (4) no excess $N$ accumulation in either organ.

The patients in the present series were selected for $\stackrel{N}{N}$ operation mainly on the basis of surface counting. $\omega$ Hence no patients who showed evidence of red cell destruction in the liver alone (pattern 2) or in whome there was no excess accumulation in either liver or $\mathbb{D}$ spleen (pattern 4) have undergone splenectomy. Thus, it has not been possible to assess the validity $\frac{T}{0}$ of the surface-counting method in cases showing $\frac{\vec{D}}{\mathrm{D}}$ patterns 2 and 4 . Sixteen of the 18 patients studied $\stackrel{\rho}{\square}$ showed pattern 1 . It might be expected that such $\AA$ patients should derive benefit from splenectomy and, 
in fact, in 15 of the patients the anaemia was either completely relieved or improved to a varying extent. As the only patient in this group (case 6) who did not respond significantly had sideroblastic anaemia as well as hereditary elliptocytosis, this should not be considered as a false prediction. Unfortunately, in this patient it was not possible to repeat the cell survival study after splenectomy and thus assess to what extent the haemolytic element responded to the operation. The findings in case 5 (see above) are relevant to this. This patient, with hereditary elliptocytosis and a dyserythropoietic anaemia, had shortened survival of red cells and evidence of increased destruction in the spleen. She derived limited benefit from the operation, with a grade III response. Red cell survival was repeated three months postoperatively and was found to be normal in spite of persistent anaemia. Thus the dyserythropoietic factor was responsible for the persistent anaemia after splenectomy, which had in fact corrected the haemolytic element.

Two patients with autoimmune haemolytic anaemia (cases 7 and 8 ) showed pattern 3, ie, excess count in both spleen and liver. It has generally been accepted on theoretical grounds that such patients eould derive only partial benefit from the operation, although there has been limited information about this situation. The fact that both these patients responded favourably is difficult to explain and indicates that further experience is needed in this group. Clearly the presence of liver activity in addition to the splenic activity should not necessarily be regarded as a feature contraindicating splenectomy.

One patient, case 10, showed a different pattern on surface counting. Clinically the patient was thought to have intravascular haemolysis, indicated by raised serum bilirubin and haemosiderinuria, in addition to some extravascular haemolysis. Surface counting was consistent with this suggestion, as the red cell destruction in the spleen (500 excess counts), which was not palpable, was unlikely to account for the severity of haemolysis $\left({ }^{51} \mathrm{Cr} \mathrm{T}_{50}\right.$ of two days). In this patient splenectomy improved the haemolytic anaemia but did not relieve it completely.

Although demonstration of accumulation of radioactivity in the spleen correlates reasonably well with the response to splenectomy, it is evident that the surface counting technique fails to give a quantitative estimation of red cell destruction in the organ. Thus, for example, patients with 400 excess counts over the spleen at ${ }^{51} \mathrm{Cr} \mathrm{T}_{50}$ (cases 11 and 12) have shown a similar response as patients with 1400 and 1350 excess counts (cases 9 and 13). It is thus not possible to predict the degree of improvement in any particular patient on the basis of this technique.
It has been suggested that a high initial spleen/liver ratio greater than 2.3 is evidence in favour of splenectomy (Goldberg, Hutchison, and MacDonald, 1966). This does not appear to be the case in the present series, as patients with an initial ratio of only $1 \cdot 2$ have responded favourably, as have patients with a rise in ratio at ${ }^{51} \mathrm{Cr} \mathrm{T}_{50}$ from a baseline of 1.0 to only $1 \cdot 2$ or 1.3 .

There are a number of possible explanations for the poor correlation between surface counting data and the degree of response to splenectomy. Surface counting provides only a rough estimate of activity in the organ because the counts obtained over the surface of an organ can be affected by a number of variable factors, eg, (1) distance of organ to body surface, (2) only part of the organ is counted in relation to its whole volume, (3) absorption of radioactivity by the surrounding tissue, (4) scattered radioactivity from other organs, and (5) loss of radioactivity from organs after its deposition (Szur, $1970 ; 1971)$.

Another reason for the lack of correlation might be the fact that splenectomy can relieve anaemia by some mechanism other than by removing the site of cell sequestration. It is known that an enlarged spleen is responsible for pooling red cells and also for haemodilution anaemia due to increased plasma volume (Prankerd, 1963; Huber, Lewis, and Szur, 1964; Toghill, 1964). Splenectomy may overcome both these effects, and these factors might have played a part in cases 11,13 , and 17 whose spleens were very large $(750 \mathrm{~g}$ and $1730 \mathrm{~g}$ respectively at operation). Unfortunately, it was not possible to repeat the isotope studies in these patients after splenectomy. Also, it has been suggested that in cases with autoimmune haemolytic anaemia splenectomy may remove the organ responsible for antibody formation; however, in the present series the antiglobulin test was unchanged after the operation and this does not appear to have been a significant factor. In cases of haemolytic anaemia secondary to myeloproliferative and lymphoproliferative disorders the improvement in anaemia after splenectomy also depends on the state of haemopoietic efficiency. The poor response seen in case 18 was almost certainly due to marked bone marrow infiltration.

Clearly, the limitation of surface counting must be recognized. A method enabling quantitative estimation of destruction of red cells in the spleen would improve the accuracy of predicting the response to splenectomy (Szur, Glass, Lewis, Grammaticos, and De Garreta, 1968). It should be emphasized, however, that while surface counting does provide a valuable technique which aids in the assessment there is need for a thorough investigation of all the factors responsible for a patient's anaemia in deciding 
whether such a patient would be likely to benefit from splenectomy.

\section{This work was supported by a grant from the Cancer Research Campaign.}

\section{References}

Allgood, J. W., and Chaplin, H., Jr. (1967). Idiopathic acquired autoimmune hemolytic anemia. Amer. J. Med., 43, 254-273.

Ben-Bassat, I., Seligsohn, U., Leiba, H., Leef, F., Chaitchik, S., and Ramot, B. (1967). Sequestration studies with chromium-51 labeled red cells as criteria for splenectomy. Israel J. med. Sci., 3, 832-837.

Dacie, J. V., and Lewis, S. M. (1968). Practical Haematology, 4th ed., Churchill, London.

Goldberg, A., Hutchinson, H. E., and MacDonald, E. (1966). Radiochromium in the selection of patients with haemolytic anaemia for splenectomy. Lancet, 1, 109-114.

Huber, H., Lewis, S. M., and Szur, L. (1964). The influence of anaemia, polycythaemia and splenomegaly on the relationship between venous haematocrit and red-cell volume. Brit. J. Haemat., 10, 567-575.

Jandl, J. H., Greenberg, M. S., Yonemoto, R. H., and Castle, W. B. (1956). Clinical determination of the sites of red cell sequestration in hemolytic anemias. J. clin. Invest., 35, 842-867.

Jones, N. C. H., and Szur, L. (1957). Determination of the sites of red cell destruction using ${ }^{81} \mathrm{Cr}$-labelled cells. Brit. $J$. Haemat., 3, 320-331.

Lewis, S. M., Szur, L., and Dacie, J. V. (1960). The pattern of erythrocyte destruction in haemolytic anaemia, as studied with radioactive chromium. Brit. J. Haemat., 6, 122-139.

McCurdy, P. R., and Rath, C. E. (1958). Splenectomy in hemolytic anemias. Results predicted by body scanning after injection of ${ }^{51} \mathrm{Cr}$ tagged red cells. New Engl. J. Med., 259, 459-463.

Prankerd, T. A. J. (1963). The spleen and anaemia. Brit, med. J., 2 517-524.

Schloesser, L. L., Korst, D. R., Clatanoff, D. V., and Schilling, R. F. (1957). Radioactivity over the spleen and liver following transfusion of chromium-51 labelled erythrocytes in hemolytic anemia. J. clin. Invest., 36, 1470-1485.

Szur, L. (1970). Surface counting in the assessment of sites of red cell destruction (Annotation). Brit. J. Haemat., 18, 591-596.

Szur, L. (1971). Blood cell survival studies. In Radioisotopes in Medical Diagnosis, edited by E. H. Belcher and H. Vetter, pp. 342-382. Butterworths, London.

Szur, L., Glass, H. I., Lewis, S. M., Grammaticos, P., and De Garreta, A. C. (1968). Quantitative estimation of red cell uptake in the spleen using ${ }^{81} \mathrm{Rb}$ and ${ }^{51} \mathrm{Cr}$ labelled red cells. Brit.J. Radiol., 41, 819-825.

Toghill, P. J. (1964). Red cell pooling in enlarged spleens. Brit J. Haemat., 10, 347-357.

Veeger, W., Woldring, M. G., Van Rood, J. J., Eernisse, J. G., Leeksma, C. H. W., Verloop, M. C., and Nieweg, H. O. (1962). The value of the determination of the site of red cell sequestration in haemolytic anaemia as a prediction test for splenectomy. Acta med. scand., 171, 507-520. 